\title{
Gray Markets
}

\section{Emirjeta Bejleri, PhD}

Lecturer, Department of Business-Administration, Faculty of Economy, University "Luigj Gurakuqi”, Shkoder, Albania

Email: emibej@yahoo.com

\section{Alba Berberi (Mirashi), PhDc}

\author{
Lecturer, Department of Business-Administration, Faculty of Economy, University “Luigj Gurakuqi”, Shkoder, Albania
}

Email: berberi_al@hotmail.com

\section{Doi:10.5901/ajis.2016.v5n3s1p467}

\section{Abstract}

In recent years has been a dramatic growth in the size of the gray market, otherwise referred to as the parallel-import market. Gray market shifts among markets \& countries because of its characteristics, its performance quality and the potential of gray market goods. A firm in an authorized marketing channel sells an authorized good to an unauthorized reseller making the good a gray market good. The firm violates in such a way the traditional business assumptions that firms and business people will behave ethically, will honor contracts and deal fairly. On the other hand the free riding of the unauthorized seller is not illegal but is unethical since the gray marketers use authorized goods and the strategy and firm's identity to achieve their objectives. Gray market goods usually have: high resale potential, trade-marketed brand names, good market recognition, established price and performance, are easily stored and inventoried, are easily transferred and have multilingual packaging. Gray market creates a potential consumer risk and reduces the performance and benefit to society. Moreover gray market can be costly and lessen control in the channel over marketing strategy. The aim of this paper is to explain first of all the meaning of the gray market, the gray market goods involved in the process, and the process itself. In the Albanian reality there is a lack of studies in this aspect therefore this paper will serve as a contribution in better understanding the topic. In the future we believe that it will serve as a base for future research in the area.

Keywords: Gray market, gray market good, authorized good, unauthorized seller, gray marketer.

\section{Introduction}

The progress of the international trade and the increase in the number of the multinational and global organizations around the world has called for the creation of an enormous number of distribution channels (Pustylnick, 2010). In recent years has been a dramatic growth in the size of the gray market, otherwise referred to as the parallel-import market. Gray marketing occurs when one party possesses the exclusive right to sell a certain product designated by a trademark in a certain area, and another party sells similar products in the same area under the same trade name (Pikard, 1996). Gray market shifts among markets \& countries because of its characteristics, its performance quality and the potential of gray market goods.

A firm in an authorized marketing channel sells an authorized good to an unauthorized reseller making the good a gray market good. The firm violates in such a way the traditional business assumptions that firms and business people will behave ethically, will honor contracts and deal fairly. On the other hand the free riding of the unauthorized seller is not illegal but is unethical since the gray marketers use authorized goods and the strategy and firm's identity to achieve their objectives.

Gray market goods usually have: high resale potential, trade-marketed brand names, good market recognition, established price and performance, are easily stored and inventoried, are easily transferred and have multilingual packaging. Gray market creates a potential consumer risk and reduces the performance and benefit to society. Moreover gray market can be costly and lessen control in the channel over marketing strategy

\section{Definition of Gray Market}

Gray market is the selling of a good away from the authorized marketing channels by an authorized seller of the good. Gray markets can arise when transaction and search costs are low enough to allow products to "leak" from one market segment back into another (Autrey \& Bova 2009). 
The development of the international trade and the increased in number of the organizations around the world has created a huge value chain formed by numerous distribution channels that increase many times the price of goods without any changes in the product. It became possible for the small entrepreneurial companies to purchase the goods legitimately in one part of the world, move them to the other part of the world, sell them at the regular markup and still have the price well below the one set through the distribution chain thus forming a gray market (Pustylnick, 2010).

Gray market shifts among markets \& countries because of its characteristics, its performance quality and the potential of gray market goods. A firm in an authorized marketing channel sells an authorized good to an unauthorized reseller making the good a gray market good. The firm violates in such a way the traditional business assumptions that firms and business people will behave ethically, will honor contracts and deal fairly. On the other hand the free riding of the unauthorized seller is not illegal but is unethical since the gray marketers use authorized goods and the strategy and firm's identity to achieve their objectives.

\section{What are Gray Market Products?}

Gray market goods are usually retail products - frequently are brand name products - that are firstly sold into a selected market but next resold through unauthorized channels into a diverse market. The legal definition of gray market goods goods of the owner such as goods with a copyright, patent, or trademark that are placed on the market by the owner but subsequently are imported into the domestic market without the rights-owner's consent. Gray marketing occurs when one party possesses the exclusive right to sell a certain product designated by a trademark in a certain area, and another party sells similar products in the same area under the same trade name (Picard, 1996). Gray market goods usually have: high resale potential, trade-marketed brand names, good market recognition, established price and performance, are easily stored and inventoried, are easily transferred and have multilingual packaging.

Usually gray market is an international activity, with the majority of goods being "gray marketed" crossing at least one border. Brand name goods that are highly desirable "hard goods" are most typically those that are gray marketed. Sometimes the gray markets have played an increasing role in improving competition for domestic goods. On the other hand, several international regulatory authorities have taken proactive attitudes toward the restriction of the firms' efforts for operating in the gray markets.

Gray market takes place in almost every industry and in every market including pharmaceuticals, automobiles, and electronics. Therefore gray markets affect a wide variety of sectors but one sector where gray markets are particularly evident is the technology sector. A survey of large high tech firms by KPMG 2008 estimates that gray markets account for $\$ 58$ billion per year of lost sales in this sector (Autrey \& Bova 2011).

Gray market goods are products originally sold in a market selected by the manufacturer, but then resold through channels not authorized by the producer (Autrey, R. L., et al., 2014). As Pustylnick 2010 stresses the gray marketers would attempt to import and sell the product only if the cost of delivery to the target market would be considerably lower in this way the gray marketer will still make a profit by selling the product at a lower price. An important source for gray market goods are often the emerging markets. Specifically, with two competing manufacturers, gray markets lead to more profits in the emerging market, but they also lead to lower profits in the domestic market (Autrey, R. L., et al., 2014).

Most manufacturers work with a single importer which is authorized to sell and support their products within a given country or geographic region and is the importer that usually establishes a channel of specific, local dealers and distributors which are authorized to resell the imported products ${ }^{1}$. For example Toshiba has a sole authorized importer in Albania which sells Toshiba-branded photocopies and accessory products in the Albania market. On the other hand there are "Toshiba-branded" products that are imported and sold by other parties using non authorized distribution channels. We will refer to these goods as gray market products. With the increase of global economy and the internet tools, gray market products have become gradually more common in the Albanian consumer goods market.

\section{Is Gray Market Illegal?}

Gray market is not visibly connected or related with a criminal activity. Gray marketing is in the majority of cases not an illegal activity but more of a question of business ethics. Unless the gray marketer has violated an explicit contract provision originating with the good or the trademark they have not performed an illegal act. The essence of this process lies in the

${ }^{1}$ http://www.fujifilmusa.com/shared/bin/130103LL1-R2_Gray_Market_Goods_Primer.pdf 
possibility of a person or another company to obtain the goods legally and sell them legally simply without the blessing of the original manufacturer and trademark owner (Schuster 2010). In most cases the offended company will not have supportive laws or their government's judicial authorities on its side. Also even in the case of explicit legal violations, the legal positions of the manufacturer's country may not cross the boundaries that the product did. Governments in the Gray Market Country may have a different laws or legal systems that highly vary from the country of the manufacturer.

Usually, from the gray market gain the short-term consumers who may (or may not) purchase a brand name good at a lower price than was intended in their authorized market. Some consumers groups argue that gray markets promote competition by keeping prices low as a result of a higher competitive pressure and on the other hand the producers argue that gray markets can weaken the company's ability to protect their brand image.

The difficulties that gray marketing causes to consumer and companies manufacturing the goods that are gray marketed are more tangible. They stem from the fact that unauthorized suppliers do not all the time offer proper levels of product support and customer service, and will sometime market old or expired goods harming in that way the reputation of the manufacturer and the trademark image. Thus the damage of brand image occurs when the confidence that the consumer has in the product is diminished.

Often the companies of origin executives are unconscious of gray market activity because it may not be apparent, so they do not recognize the fact that their products are selling in the gray market. Also sometimes managers may have an ethnocentric and somewhat egocentric viewpoint about gray marketing. This viewpoint may lead them to believe that since they consider gray marketing to be wrong doing all of the other individuals in their marketing chain will share the same beliefs whether they are from a different culture or have a different personal perspective.

Ideally a company should discover these markets through their own research efforts and positive business experience rather than by being a victim of gray marketing. Hopefully then they may pursue these markets by making adaptations to their products or marketing them differently in these markets.

\section{What Can be Done about Gray Market?}

- Prohibitions against gray market goods vary from country to country.

- Some countries or regions recognize international exhaustion of rights (no ability to take action under trademark law after first sale anywhere in the world) and others national exhaustion (legal options available if goods come from outside the country).

- EU has a distinct approach depending on whether goods are from within or outside the region.

- Not all gray goods are illegal; the law of each region or country must be reviewed.

The management of a firm should try to resolve internal causes associated with gray marketing such as pricing, customer service, distributor contacts, sales force, and lack of effective measurements to evaluate the performance of its distribution channels. Management policies which do not recognize the problems and the pressures that higher sales quotas and progressively shortened distribution expectations place on sales managers further down the line are partially responsible for the development of gray markets. Sellers who are forced to meet ever increasing sales quotas may be forced to divert goods.

If a company wants to protect itself from gray marketing, it must put in place some strategies in order to fight against gray market activity. Thus the company should take some actions to avoid, prevent or decrease the effects caused by gray market. In many markets although gray marketing activity is not always apparent therefore it is useful for managers to be focused toward the markets in which they operate, before unauthorized goods affect their efforts.

Advances in information technology may give to the business an opportunity to take advantage of information to recognize and forecast gray market activity. Management may conduct primary and secondary research in order to gather information about the distribution of their products. This may be critical for monitoring, forecasting and identification of gray marketing activity because by using controls over their products and over product services will allow companies to monitor gray marketing activity.

Companies however should consider the effort and the amount of capital they put into the enterprise, intended for discouraging gray markets, as capital that is diverted from other aspects of the development and marketing of the firm's goods. The company itself will be paying for the investigations and modifications needed to protect their products journey to authorized end markets. A balance must be achieved between efforts to stop the drain that gray marketing makes on the firms resources and using the firm's resources for doing other business. Hopefully company's efforts to combat gray market activity would result in a more effective management of sales and distribution channels overall and the effective coordination of the distribution channels. 


\section{Conclusions}

- Gray market shifts among markets \& countries because of its characteristics, its performance quality and the potential of gray market goods.

- A firm in an authorized marketing channel sells an authorized good to an unauthorized reseller making the good a gray market good. The firm violates in such a way the traditional business assumptions that firms and business people will behave ethically, will honor contracts and deal fairly.

- The free riding of the unauthorized seller is not illegal but is unethical since the gray marketers use authorized goods and the strategy and firm's identity to achieve their objectives.

- Gray market goods usually have: high resale potential, trade-marketed brand names, good market recognition, established price and performance, are easily stored and inventoried, are easily transferred and have multilingual packaging.

- Brand name goods that are highly desirable "hard goods" are most typically those that are gray marketed.

- Gray market creates a potential consumer risk and reduces the performance and benefit to society.

- Gray market can be costly and lessen control in the channel over marketing strategy.

- In the future we believe that this paper will serve as a base for future research in the area.

\section{References}

Autrey \& Bova (2009) Gray market and multinational transfer pricing. Working paper Harvard Business School, 2009 http://www.hbs.edu/faculty/Publication\%20Files/09-098.pdf

Autrey, R. L. \& Bova, F., (2011) Gray Markets and Multinational Transfer Pricing Harvard Business School Accounting \& Management Unit Working Paper No. 09-098; Accounting Review, Forthcoming. Available atSSRN: https://ssrn.com/abstract=1351883

Autrey, R. L., et al. (2014) When Gray is Good: Gray Markets and Market-Creating Investments. Production and Operations Management April 2015 V. 24, Issue 4: pp 547-559, http://onlinelibrary.wiley.com/doi/10.1111/poms.12254/abstract

Pustylnick I., (2010) Gray Marketing as Indication of Price Strategy Deficiency Based on the real life case from Canadian Knitting Craft Industry, Swiss Management Center (www.swissmc.ch) 2010 https://papers.ssrn.com/sol3/papers.cfm?abstract_id=1680070

Picard J, (1996), "Legality of international gray marketing. A comparison of the position in the United States Canada and the European Union.", 26 Can. Bus. L.J. 422.

Schuster WG, (2010), "US High Court Will Decide Omega Gray Market Case", JCK http://www.jckonline.com/article/457015U_S_High_Court_Will_Decide_Omega_Gray_Market_Case.php

http://www.fujifilmusa.com/shared/bin/130103LL1-R2_Gray_Market_Goods_Primer.pdf

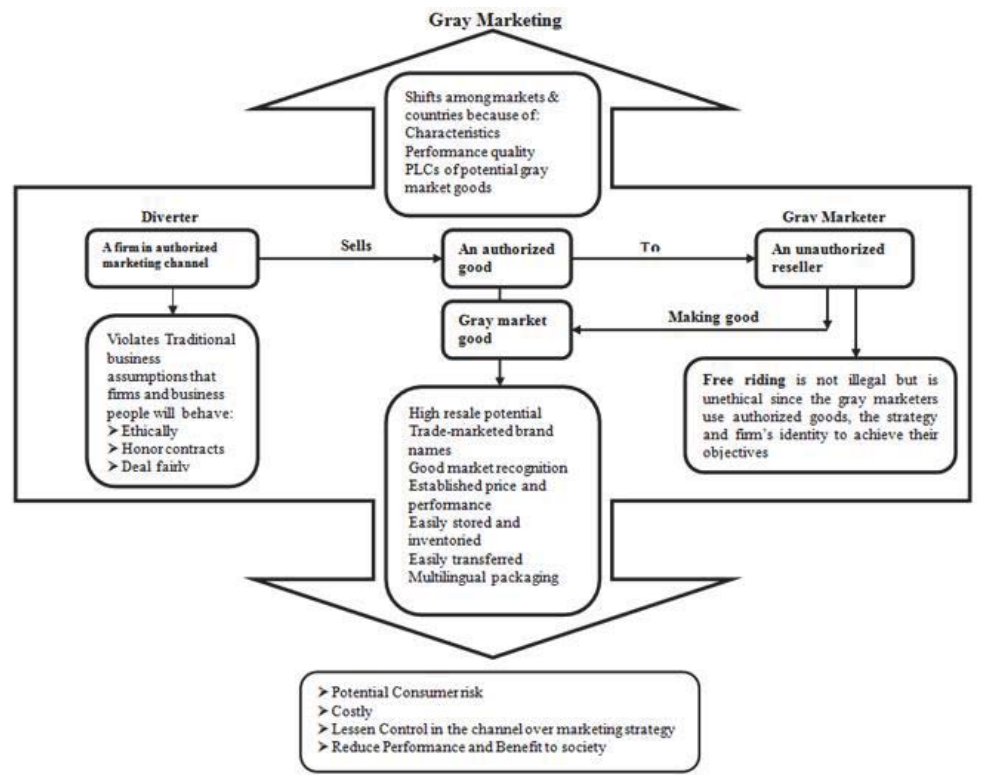

